\title{
PEMBELAJARAN KONTEKSTUAL DENGAN STRATEGI REACT BERBANTUAN MEDIA UNTUK MENINGKATKAN AKTIVITAS DAN HASIL BELAJAR IPS
}

\author{
Sigit Kindarto, Abdul Gafur \\ SMP Negeri 7 Cilacap, Universitas Negeri Yogyakarta \\ aedadonk@yahoo.com,agafur68@gmail.com
}

\begin{abstract}
Abstrak
Penelitian ini bertujuan untuk: (1) meningkatkan aktivitas belajar dan (2), meningkatkan hasil belajar IPS melalui pembelajaran kontekstual dengan strategi REACT berbantuan media pada kelas IX F SMP Negeri 7 Cilacap. Penelitian ini merupakan penelitian tindakan kelas (classroom action research) menggunakan desain Kemmis \& Taggart. Teknik pengumpulan data yang digunakan adalah observasi dan tes hasil belajar. Berdasarkan hasil penelitian dapat disimpulkan: (1) terjadi peningkatan aktivitas belajar siswa dalam pembelajaran kontekstual dengan strategi REACT berbantuan media. Pada kondisi awal rata-rata aktivitas belajar siswa $41,07 \%$ dari 32 siswa, akhir siklus I meningkat menjadi 68,30\%; dan akhir siklus II menjadi 85,15\%, (2) ada peningkatan ketuntasan hasil belajar siswa dari kondisi awal hanya 43,75\% siswa tuntas belajar, menjadi 71,88\% di akhir siklus I dan akhir siklus II menjadi 87,50\%.
\end{abstract}

Kata Kunci: pembelajaran kontekstual, strategi REACT, media, aktivitas belajar, hasil belajar IPS.

\section{CONTEXTUAL LEARNING TO REACT ASSISTED MEDIA STRATEGY TO ENHANCE LEARNING ACTIVITIES AND RESULTS SOCIAL SCIENCE}

\author{
Sigit Kindarto, Abdul Gafur \\ SMP Negeri 7 Cilacap, Universitas Negeri Yogyakarta \\ aedadonk@yahoo.com,agafur68@gmail.com
}

\begin{abstract}
This study to investigate about: (1) the increase in the activity progress learning, (2)) getting the improvement of and the learning result of social studies in class IX F SMP Negeri 7 Cilacap, after the implementing of Contextual Teaching and Learning to REACT Strategy using the media. This research was a classroom action research using Kemmis \& Taggart design. The collecting data technical used were observation and result test. Based on the results of this study concluded: (1) there was improvement in student learning activities with application of contextual teaching and learning of REACT strategy using the media newspaper and media voucher card. In pre cycle average $41.07 \%$ of student learning activity, the first cycle increased to $68.30 \%$ and second cycle students'learning activities be $85.15 \%$, (2) there was an increasing mastery of student learning outcomes on the application of contextual teaching and learning using the media. In the pre cycle only $43.75 \%$ of students pass the study, in the first cycle mastery learning students $71.88 \%$ and second cycle becomes be $87.50 \%$.
\end{abstract}

Keywords : contextual teaching and learning, media, activity, learning result of social studies. 


\section{Pendahuluan}

Pendidikan merupakan sebuah proses dengan metode-metode tertentu sehingga orang memperoleh pengetahuan, pemahaman, dan cara bertingkah laku yang sesuai dengan norma kehidupan. Sebagian orang memahami arti pendidikan sebagai pengajaran/pembelajaran karena pendidikan pada umumnya selalu membutuhkan pengajaran baik dari orang tua, sekolah, atau lingkungan masyarakat.

Untuk mewujudkan terlaksananya pendidikan tersebut ditindaklanjuti dengan upaya konkret, antara lain penambahan peralatan yang mendukung proses pembelajaran, pengadaan peralatan laboratorium, pencetakan buku-buku pelajaran dan perpustakaan, yang kesemuanya itu untuk meningkatkan mutu pendidikan. Metode pembelajaran banyak diciptakan untuk memberikan kemudahan dalam proses pembelajaran karena belum banyak diimplementasikan guru.

Dalam proses pembelajaran terdapat dua pihak yang sinergik, yakni guru mengajar dan siswa belajar. Guru mengajarkan bagaimana siswa harus belajar. Sementara siswa belajar bagaimana seharusnya belajar melalui berbagai pengalaman belajar sehingga terjadi perubahan dalam dirinya dari aspek kognitif, afektif dan psikomotorik. "Keaktifan siswa menjadi unsur amat penting dalam menentukan kesuksesan belajar. Aktivitas mandiri adalah jaminan untuk mencapai hasil belajar yang sejati" (Budiningsih, 2012:p.5). Guru yang kompeten akan lebih mampu menciptakan lingkungan yang efektif dan akan lebih mampu mengelola proses belajar mengajar, sehingga hasil belajar siswa berada pada tingkat yang optimal (Ajoku, 2013:p.15). Mengembangkan pendekatan/metode pengajaran merupakan salah satu upaya untuk meningkatkan kualitas belajar siswa.

Seorang pendidik dituntut untuk menguasai pendekatan pembelajaran karena dapat membantu pendidik untuk mempermudah tugasnya dalam menyampaikan mata pelajaran tersebut. Pendidik dituntut untuk menerapkan tiga ranah dalam pendidikan yaitu aspek kognitif, afektif, dan psikomotor serta guru diharapkan mampu melihat tingkat kemampuan yang dimiliki oleh siswa, baik itu siswa yang visual, auditorial maupun kinestik.

Hasil observasi pembelajaran di SMP Negeri 7 Cilacap pada 22, 24, 27 dan 31 Agustus 2013 menujukkan bahwa kondisi ideal tersebut di atas belum tercipta. Kenyataan di lapangan, proses pembelajaran bersifat transfer of knowledge, metode presentasi/konvensional, guru sebagai satu-satunya sumber belajar yang serba tahu informasi, siswa pasif terlihat dari minimnya akivitas yang dilakukan dalam merespon proses pembelajaran, materi pembelajaran hanya untuk dihafal tanpa diberi tahu kegunaan materi tersebut dalam kehidupan nyata. Korelasi antara materi pembelajaran dengan kenyataan hidup tidak tampak pembelajaran bersifat textual learning dan content oriented. Hasil belajar yang diperoleh siswa pada mata pelajaran IPS berdasarkan nilai ulangan harian yang diperoleh rendah sebagaimana terlihat dalam tabel berikut:

Tabel 1. Nilai Ulangan Harian Pertama Mata Pelajaran IPS Kelas IX

\begin{tabular}{lcccccccc}
\hline \multirow{2}{*}{ Kriteria } & \multicolumn{8}{c}{ Mata Pelajaran IPS/Kelas IX } \\
\cline { 2 - 9 } & A & B & C & D & E & F & G & H \\
\hline Nilai Tertinggi & 98 & 93 & 90 & 89 & 92 & 92 & 95 & 97 \\
Nilai Terendah & 72 & 56 & 69 & 50 & 63 & 48 & 70 & 70 \\
KKM & 72 & 72 & 72 & 72 & 72 & 72 & 72 & 72 \\
Rata-rata & 75 & 70 & 70 & 70 & 71 & 62 & 71 & 70 \\
Siswa $\geq$ KKM & 34 & 30 & 28 & 31 & 29 & 14 & 31 & 29 \\
Siswa $\leq$ KKM & 0 & 4 & 6 & 3 & 5 & 18 & 3 & 3 \\
JML SISWA & 34 & 34 & 34 & 34 & 34 & 32 & 34 & 32 \\
\hline
\end{tabular}


Berdasarkan tabel tersebut terlihat kelas IXF merupakan kelas dengan jumlah siswa terbanyak yang tidak tuntas KKM yaitu sebanyak 18 siswa atau 56,25\%, dibandingkan dengan ketujuh kelas lainnya. Hal ini memberikan sinyal adanya masalah di Kelas IXF dalam proses pembelajarannya. Oleh karena itu, perlu diupayakan solusi mengatasi permasalahan tersebut diselaraskan dengan perkembangan pendekatan pembelajaran.

Proses pembelajaran yang memberikan kesempatan kepada siswa untuk mengalami sendiri, menemukan dan mengaitkan ilmu dengan kehidupan nyata akan menjadikan siswa tidak hanya tahu secara kognitif tetapi mampu berpikir kritis dan kreatif dalam pembelajaran dan mencapai hasil belajar yang sejati (Cazan, 2013:p.743). Pendekatan pembelajaran yang seperti itu adalah Pembelajaran Kontekstual.

\section{Metode Penelitian}

Jenis Penelitian

Penelitian ini merupakan Penelitian Tindakan Kelas (Classroom Action Research). Menurut Kemmis \& Mc Taggart (1990:p.11). Rangkaian siklus penelitian tindakan yang dilakukan dapat digambarkan sebagai berikut :

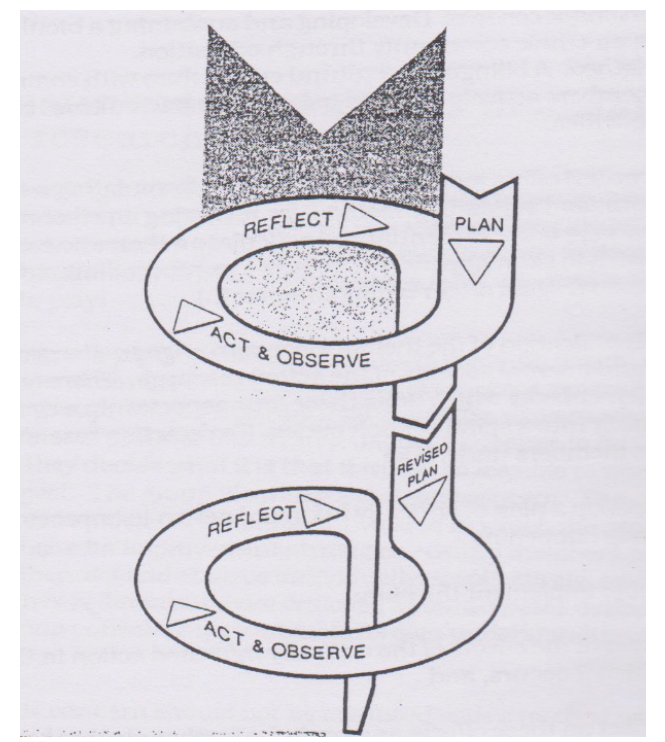

Gambar 1. Model PTK Kemmis \& Taggart

Waktu dan Tempat Penelitian

Waktu penelitian dilaksanakan pada semester satu tahun pelajaran 2013/2014 dari bulan Agustus - Oktober 2013, selama 13 minggu bertempat di SMP Negeri 7 Cilacap dengan rincian sebagai berikut:
Alokasi Waktu

Tabel 2. Alokasi Waktu Penelitian

\begin{tabular}{|c|c|c|}
\hline No & Spesifikasi Tahapan & $\begin{array}{c}\text { Total } \\
\text { Waktu / } \\
\text { (Minggu) } \\
\end{array}$ \\
\hline \multirow[t]{5}{*}{$\mathrm{a}$} & $\begin{array}{l}\text { 1) Tahap perencanaan (penyu- } \\
\text { sunan usulan dan instrument } \\
\text { penelitian) }\end{array}$ & 2 minggu \\
\hline & $\begin{array}{l}\text { 2) Tahap pelaksanaan tinda- } \\
\text { kan (meliputi: plan, action, } \\
\text { observation dan reflection) }\end{array}$ & 6 minggu \\
\hline & 3) Tahap pengolahan data & 2 minggu \\
\hline & $\begin{array}{l}\text { 4) Tahap penyusunan laporan } \\
\text { hasil penelitian }\end{array}$ & 2 minggu \\
\hline & $\begin{array}{l}\text { 5) Tahap penyampaian infor- } \\
\text { masi pada subjek penelitian } \\
\text { (Diseminasi) }\end{array}$ & 1 minggu \\
\hline $\mathrm{b}$ & Total waktu yang diperlukan & 13 minggu \\
\hline
\end{tabular}

Subjek Penelitian

Siswa kelas IX F yang berjumlah 32 orang. Kelas ini dipilih dengan alasan bahwa kelas ini tergolong kurang dalam aktivitas dan hasil belajarnya dibandingkan dengan enam kelas lainnya berdasarkan hasil perolehan hasil ulangan harian. Ketuntasan belajar yang dicapai di kelas IX F hanya $43,75 \%$ berdasarkan hasil observasi prapenelitian. Indikator lain adalah suasana belajar di kelas tidak kondusif ditandai dengan siswa ramai saat pelajaran berlangsung, tidak fokus, banyak yang tidak memperhatikan guru saat ada penjelasan.

\section{Prosedur/Rencana Tindakan}

Jenis tindakan yang akan dilakukan dalam penelitian ini adalah menerapkan pendekatan pembelajaran kontekstual berbantuan media dalam pembelajaran IPS dengan menggunakan strategi REACT.

Data, Intrumen, dan Teknik Pengumpulan Data

Untuk memperoleh informasi, data yang representatif dan signifikan dari proses dan aktivitas pembelajaran serta situasi lain yang mempengaruhi pembelajaran, maka peneliti memilih beberapa teknik dalam pengumpulan data sebagai berikut:

\section{Observasi/Pengamatan}


Observasi dilaksanakan untuk mendapatkan data-data yang diperlukan sebagai dasar untuk melakukan penelitian lebih lanjut. Kegiatan observasi dilakukan pada setiap pertemuan pembelajaran. Pada pelaksanaan observasi, peneliti bertugas mengamati kinerja guru dan aktivitas siswa dengan instrumen yang sudah disusun peneliti sebelumnya

\section{Tes Hasil Belajar}

Tes digunakan untuk mengetahui perkembangan atau keberhasilan hasil belajar siswa yang dilakukan secara tertulis pada setiap akhir siklus penelitian

\section{Instrumen Penelitian}

Proses pengumpulan data dilakukan peneliti dengan menggunakan instrumen observasi penelitian dan instrumen perangkat tes hasil belajar. Secara spesifik instrumen tersebut dijelaskan sebagai berikut:

\section{Lembar observasi aktivitas belajar siswa}

Instrumen ini berupa ckhec list $(\sqrt{ })$ dan catatan pengamatan terhadap aktivitas belajar siswa dan aktualisasinya selama proses pembelajaran.

\section{Instrument tes hasil belajar}

Perangkat tes terdiri dari kisi-kisi tes uji kompetensi, soal tes kompetensi hasil belajar siswa persiklus dan kunci jawaban tes. Tes disajikan dengan serangkaian pertanyaan yang harus dijawab dengan benar oleh siswa secara tertulis dalam bentuk soal pilihan ganda dan uraian. Hasil dari tes uji kompetensi ini digunakan sebagai acuan untuk menganalisis hasil belajar siswa setiap akhir siklus kegiatan penelitian.

\section{Jurnal harian}

Catatan kegiatan selama proses pembelajaran yang digunakan untuk melihat progress / kemajuan dan berfungsi untuk mengoptimalkan refleksi kegiatan penelitian tindakan kelas.

\section{Teknik Analisis Data}

Data yang diperoleh pada penelitian ini berupa data kualitatif dan kuantitatif. Data kualitatif meliputi data yang diperoleh pada saat kegiatan observasi, sedangkan data kuantitatif diperoleh dari data hasil belajar. Adapun secara spesifik teknik analisis data dijelaskan sebagai berikut:

\section{Teknik Analisis Hasil Observasi}

Data hasil observasi yang diperoleh pada setiap siklus penelitian digunakan sebagai acuan pendukung untuk melakukan proses analisis pada kegiatan refleksi. Proses analisis data dilaksanakan dengan mengidentifikasi keberhasilan, kendala dan solusi yang akan diterapkan peneliti pada tahapan berikutnya. Adapun penyajian data dilakukan secara kualitatif intepretatif yang pada akhirnya akan menghasilkan sebuah makna pada analisis hasil penelitian yang dilakukan.

\section{Teknik Analisis Data Aktivitas Belajar}

Data aktivitas belajar siswa diperoleh dengan cara mencari skor hasil pengamatan pada setiap pertemuan. Kisi-kisi aktivitas siswa yang diamati dalam penelitian ini adalah sesuai dengan prinsip-prinsip pembelajaran kontekstual. Indikator Kriteria pengamatan aktivitas dalam penelitian ini ada tujuh item meliputi: (a) memperhatikan penjelasan guru, (b) bertanya (questioning), (c) menjawab dan merespon pertanyaan guru, (d) aktif berdiskusi (learning community), (e) mengerjakan tugas / soal latihan (inquiry), (f) mempresentasikan hasil dari latihan (reflection), (g) aktif mencatat/ merangkum

Pedoman penilaian pengamatan yang digunakan untuk melakukan penskoran pada tiap aspek amatan aktivitas belajar siswa adalah skala 0 dan 1 . Skor maksimal dari aktivitas belajar adalah 1 skor maksimal dari setiap indikator $\mathrm{x} 7$ indikator $=7$. Berikut disajikan pedoman penilaian dan rumus mencari persentase aktivitas belajar siswa:

a. Pedoman penilaian aspek pengamatan aktivitas belajar siswa:

Tabel 3. Skor Pengamatan Aktivitas Siswa

\begin{tabular}{ccc}
\hline No & Skor & Keterangan Aktivitas \\
\hline 1 & 0 & Tidak \\
2 & 1 & Ya \\
\hline
\end{tabular}

b. Rumus skor pengamatan aktivitas belajar siswa

$$
\mathrm{S}=\frac{\text { Skor Hasil Pengamatan }}{\text { Skor maksimal ideal }} \text { X } 100
$$

\section{Keterangan:}

$\mathrm{S}=$ Skor pengamatan aktivitas siswa

Skor hasil pengamatan $=$ Akumulasi dari jumlah skor dalam lembar pengamatan

Skor maksimal ideal $=$ Akumulasi dari jumlah 
skor dengan jumlah aspek aktivitas pembelajaran $100=$ Bilangan tetap

Untuk mengetahui skor rata-rata hasil pengamatan siswa secara keseluruhan dilakukan dengan menjumlahkan hasil skor rata-rata tiap pertemuan dibagi skor maksimal kemudian dikalikan 100. Kemudian hasil pengamatan dianalisis dengan mengkonversi skor aktivitas ke dalam pedoman konversi sebagai berikut:

Tabel 4. Pedoman Konversi Skor Aktivitas

\begin{tabular}{ccccc}
\hline \multirow{2}{*}{ No } & Skor & \multicolumn{2}{c}{ Nilai Konversi } & \\
\cline { 3 - 4 } & Total & Angka & Huruf & \\
\hline 1 & $6-7$ & $71-100$ & A & Sangat tinggi \\
2 & $4-5$ & $51-70$ & B & Tinggi \\
3 & $2-3$ & $31-50$ & C & Sedang \\
4 & $0-1$ & $10-30$ & D & Rendah \\
\hline
\end{tabular}

Sumber: Diadopsi dari Suwandi, (2009:p.128).

\section{Teknik Analisis Data Hasil Belajar}

Data hasil belajar siswa diperoleh dari pelaksanaaan tes uji kompetensi pada setiap akhir siklus untuk dianalisis. Hasil belajar tersebut kemudian dianalisis dengan menggunakan statistic desriptif. Teknik analisis data hasil belajar siswa menggunakan pedoman:

a. Kriteria ketuntasan minimal (KKM) yang ditetapkan oleh guru dan sekolah sebesar $\geq$ 72

b. Ketuntasan belajar klasikal

$$
\mathrm{TB}=\frac{\sum \mathrm{S} \geq 72}{\mathrm{n}} \times 100 \%
$$

Keterangan:

$\begin{array}{ll}\text { TB } & \text { : } \begin{array}{l}\text { Ketuntasan belajar } \\ \text { Jumlah siswa yang menda- }\end{array} \\ \sum \mathrm{S} \geq 72: & \begin{array}{l}\text { pat nilai lebih besar dari atau } \\ \text { sama dengan } 72\end{array} \\ \mathrm{n} \quad: \begin{array}{l}\text { Banyaknya siswa yang } \\ \text { mengikuti tes }\end{array} & \text { Bilangan tetap }\end{array}$

\section{Hasil Penelitian dan Pembahasan}

Siklus 1

Penelitian tindakan kelas ini dilakukan sebanyak dua siklus, dan setiap siklusnya dengan dua kali pertemuan, setiap pertemuan dilaksanakan selama 80 menit. Penelitian ini dilakukan secara kolaboratif, dengan satu guru IPS yang berstatus PNS sebagai model yang diamati dan peneliti sebagai supervisor.

Pada setiap siklus, prosedur dalam penelitian tindakan mencakup empat tahap yaitu: 1) perencanaan, 2) tindakan, 3) observasi dan 4) refleksi.

\section{Perencanaan}

\section{Pertemuan pertama}

Pada tahap perencanaan, peneliti melakukan diskusi dengan kolaborator mengenai silabus, RPP dan metode pembelajaran yang akan digunakan dalam proses pembelajaran serta penyusunan lembar observasi, maupun penyiapan media pembelajarannya. Media bantu pembelajaran yang disiapkan adalah media massa cetak (surat kabar) Suara Merdeka, yang berjumlah 16 bendel yang akan dibagikan kepada setiap kelompok diskusi, yang direncanakan ada 8 kelompok dengan 4 anggota setiap kelompoknya. Peneliti dan kolaborator juga membuat slide powerpoint untuk menunjang penjelasan materi pembelajaran (Lampir

Pembelajaran yang digunakan dalam penelitian ini guru akan menerapkan pembelajaran kontekstual dengan strategi REACT yaitu 1) Relating yaitu mengaitkan pembelajaran dengan lingkungan sekitar siswa atau konteks pengalaman kehidupan sehari-hari yang berupa jenisjenis kegiatan yang mengancam kemerdekaan di era global yang dimuat di media massa cetak (surat kabar) Suara Merdeka, seperti berita tentang korupsi, gerakan separatisme, bahaya laten komunis, aksi terorisme, tawuran pelajar, kerusuhan atas nama SARA, maupun narkoba, 2) Experiencing artinya Pembelajaran lebih memberikan kegiatan eksplorasi, penemuan langsung, produktif dan mampu menumbuhkan penguatan konsep kepada siswa dengan melakukan penemuan berita di media massa cetak (Surat Kabar) Suara Merdeka yang terkait dengan materi pembelajaran disiapkan oleh kolaborator, 3) Appliying yaitu guru menerapkan pembelajaran yang membimbing siswa untuk mengaplikasikan materi pelajaran dalam situasi lain yang berbeda dengan menganalogkan hasil analisis berita di media cetak dalam kehidupan riil di lingkungan siswa, misalnya apa yang akan dilakukan jika di lingkungannya terdapat orang yang terlibat narkoba, koruptor 4) Cooperating yaitu melatih 
siswa untuk bekerjasama, mengemukakan pendapat, mengajukan dan menjawab pertanyaan, komunikasi interaktif antar siswa dengan guru serta nara sumber maupun presentasi dalam diskusi, 5) Transferring yaitu pembelajaran yang menekankan pada kemampuan mentransfer pengetahuan, ketrampilan, dan sikap yang telah dimilikinya. Siswa dapat mengatasi ancaman terhadap kemerdekaan baik secara preventif maupun reaktif berdasarkan pemahaman dari materi pembelajaran.

Guru setelah melakukan interaksi pembelajaran menggunakan slide powerpoint kemudian membentuk delapan (8) kelompok diskusi dengan 4 anggota setiap kelompoknya. Setiap kelompok bebas memberi nama kelompoknya dengan menggunakan nama salah satu pulau yang ada di Indonesia. Tujuan penggunaan nama pulau ini adalah mengenalkan nama pulau-pulau di Indonesia dan menanamkan rasa cinta kepada tanah airnya. Setelah kelompok terbentuk, kemudian guru membagikan media bantu berupa media cetak Suara Merdeka, kepada setiap kelompok masing-masing 2 bendel. Selanjutnya guru memandu atau memfasilitasi pelaksanaan diskusi kelas.

\section{Pertemuan kedua}

Peneliti menyusun RPP dan menyiapkan lembar observasi beserta media bantu yang akan digunakan dalam pembelajaran. Media bantu dalam pembelajaran ini tetap menggunakan Media Massa Cetak dari Harian Umum Suara Merdeka yang disiapkan sebanyak 16 bendel. Alat evaluasi berupa soal-soal post test juga dibuat untuk mengetahui hasil pembelajaran yang telah dilaksanakan dengan pendekatan kontekstual berbantuan media massa cetak ini. Uji kompetensi yang akan dilaksanakan adalah berbentuk tes tertulis, pilihan ganda sebanyak 20 butir dan 4 butir soal terkait media bantu dalam pembelajaran yang dilakukan guru untuk mengetahui sikap (afektif) siswa terhadap penggunaan media bantu pembelajaran dalam kompetensi dasar yang ajarkan.

\section{Pelaksanaan Tindakan}

\section{Pertemuan Pertama}

Penelitian tindakan kelas pada siklus I dilaksanakan sebanyak 2 kali pertemuan/tatap muka. Pertemuan pertama penelitian ini dilaksanakan pada hari Selasa tanggal 24 September 2013 di kelas IXF. Pembelajaran pada jam pertama dan kedua. Guru masuk kelas pukul 07.20 WIB. Guru mengajak siswa melakukan doa memulai pelajaran yang dipimpin oleh ketua kelas, kemudian setelah selesai berdoa seluruh siswa mengucapkan salam kepada guru. Presensi kehadiran siswa selanjutnya merupakan tindakan yang dilakukan oleh guru. Materi pembelajaran yang disampaikan pada siklus I pertemuan pertama ini dengan Standar Kompetensi (SK) 2. Memahami usaha mempertahankan kemerdekaan dengan Kompetensi Dasar (KD) 2.1 Mengidentifikasi usaha perjuangan mempertahankan kemerdekaan dengan materi pokok yang dipelajari adalah Mendeskripsikan perjuangan rakyat dan pemerintah di berbagai daerah dalam usaha mempertahankan kemerdekaan Indonesia. Guru menyampaikan indicator dan tujuan pembelajaran yang akan dicapai dalam pembelajaran tersebut. Alokasi waktu yang digunakan untuk proses pembelajaran ini adalah $2 \times 40$ menit (dua jam pelajaran).

Guru menyampaikan presentase pembelajaran dengan menggunakan Powerpoint melalui LCD (Liquid Crystal Display). Guru berusaha menarik perhatian belajar siswa dengan menampilkan tayangan slide yang dibuat difokuskan pada materi berupa jenis-jenis ancaman kemerdekaan Indonesia, baik pasca kemerdekaan maupun ancaman kemerdekaan pada era global sekarang ini. Guru dalam presentasi slide ini memakai alat slide laser sehingga guru dapat mobile bergerak mendekat ke siswa dan dapat menunjukkan gesture-nya ketika mengajar, tidak hanya diam berada di belakang laptop untuk mengganti slide berikutnya. Hal tersebut menjadikan siswa tertarik mengikuti pembelajaran IPS.

Tahap selanjutnya guru menyiapkan alat bantu pembelajaran berupa media massa cetak yaitu Suara Merdeka untuk dibagikan kepada siswa secara berkelompok, kemudian guru membentuk kelompok diskusi. Jumlah siswa 32 kemudian dibagi menjadi 8 kelompok, dan setiap kelompok dengan 4 orang anggota. Pembagian kelompok diskusi ini didasarkan pada nomor urut absen. Setiap kelompok memberi nama kelompoknya dengan menggunakan nama-nama pulau di Indonesia, dan yang disepakati adalah Pulau 
Bali, Pulau Nusakambangan, Pulau Jawa, Pulau Sulawesi, Pulau Madura, Pulau Komodo, Pulau Sumatera dan Pulau Kalimantan. Tujuan penggunaan nama pulau sebagai nama kelompok adalah dalam rangka menanamkan rasa cinta pada tanah air. Setelah kelompok diskusi terbentuk kemudian guru menjelaskan apa yang harus dikerjakan oleh setiap kelompok, yaitu menganalisis berbagai berita di media cetak yang akan segera dibagikan kepada setiap kelompok mengenai pemberitaan yang termasuk dalam kategori mengancam kemerdekaan Indonesia di era global. Kemudian guru membagikan sebanyak 16 bendel media cetak Suara Merdeka kepada setiap kelompok diskusi masing-masing 2 bendel. Guru juga membagi format isian hasil diskusi untuk digunakan dalam meresum hasil diskusi.

Diskusi berlangsung, siswa berusaha menemukan berbagai ancaman kemerdekaan dengan meniliti pemberitaan di Suara Merdeka kemudian setelah menemukan materi yang diinginkan dilanjutkan diskusi kelompok dengan memberikan penjelasan-penjelasan kenapa materi berita tersebut dapat dikategorikan mengancam kemerdekaan. Setelah dicapai kata sepakat dalam kelompok kemudian sekretaris kelompok menulis hasil rumusan kelompok ke dalam lembar jawaban kelompok yang telah diberikan oleh guru bersamaan membagikan media cetak. Setelah semua kelompok menyelesaikan diskusinya, dilanjutkan kegiatan presentasi.

Hasil diskusi kemudian dipresentasikan oleh setiap kelompok dan ditanggapi oleh kelompok lain. Respon dari kelompok lain kemudian dijawab oleh kelompok presenter. Perbedaan pendapat yang ekstrem antara kelompok presenter dengan yang melakukan respon akan dibahas dengan guru di akhir session diskusi. Kelompok yang melakukan presentasi diawali oleh kelompok "Pulau Bali" kemudian dilanjutkan oleh tujuh kelompok lainnya secara bergilir. Rumusan hasil learning community / diskusi.

\section{Pertemuan Kedua}

Pertemuan kedua dilaksanakan pada hari Kamis tanggal 26 September 2013. Guru dan kolaborator masuk kelas pada jam pelajaran pertama sampai dengan kedua yang dimulai pukul 07.20 - 08.40 WIB. Pembelajaran diawali dengan melakukan doa bersama yang dipimpin oleh ketua kelas kemudian guru mengucapkan salam assalamu'alaikum dan selamat pagi kepada seluruh siswa dan dijawab dengan ucapan wa'alaikum salam dan selamat pagi. Guru kemudian menanyakan kepada siswa apakah ada temannya yang tidak berangkat, dan ternyata semua siswa masuk. Peneliti duduk dipojok kanan deretan paling belakang kursi siswa.

Pertemuan pembelajaran kali ini melanjutkan materi sebelumnya yaitu Standar Kompetensi (SK) 2. Memahami usaha mempertahankan kemerdekaan dengan Kompetensi Dasar (KD) 2.1 Mengidentifikasi usaha perjuangan mempertahankan kemerdekaan dengan materi pokok yang dipelajari adalah Mendeskripsikan perjuangan rakyat dan pemerintah di berbagai daerah dalam usaha mempertahankan kemerdekaan Indonesia

Pembelajaran pertemuan kedua fokus pembahasan adalah upaya mempertahankan kemerdekaan Indonesia. guru menanyangkan slide pada program powerpoint. Kajian materi yang diberikan menggunakan powerpoint ini adalah peristiwa pasca kemerdekaan dan upaya mempertahankan kemerdekaan di era informasi dan teknologi saat ini (globalisasi). Guru menampilkan contoh-contoh upaya yang telah dilakukan oleh para pendiri negara dalam upaya mempertahankan kemerdekaan, diantaranya dengan cara perlawanan fisik (peperangan frontal) dan juga diplomasi, selain itu guru juga menjelaskan cara mempertahankan kemerdekaan di jaman modern (globalisasi) saat ini. Setelah selesai presentasi kemudian guru memerintahkan kepada siswa agar berkelompok sesuai dengan kelompok diskusi pada pertemuan pertama.

Setelah siswa duduk sesuai dengan kelompoknya kemudian guru membagikan Surat Kabar Suara Merdeka sejumlah 16 bendel kepada siswa dengan rincian setiap kelompok mendapatkan 2 (dua) bendel. Tugas yang harus dikerjakan siswa adalah mencari pemberitaan yang mencerminkan perilaku atau tindakan ikut serta mempertahankan kemerdekaan Indonesia di era global.

Hasil diskusi kelompok kemudian dipresentasikan oleh setiap kelompok dan ditanggapi oleh kelompok lain. Respon dari kelompok lain hanya diberi kesempatan satu kali. Apabila terjadi deadlock antara kelompok penyaji dengan 
yang melakukan respon akan dibahas dengan guru di akhir session diskusi. Kelompok yang melakukan presentasi diawali oleh kelompok "Pulau Madura" kemudian dilanjutkan oleh tujuh kelompok lainnya secara bergilir. Rumusan hasil learning community / diskusi.

\section{Observasi Aktivitas dan Hasil Belajar Siswa}

Siswa cukup aktif dan antusias selama proses pembelajaran berlangsung. Siswa umumnya menyimak pembelajaran dengan tekun, hanya ada satu-dua anak yang mengobrol sendiri ketika guru menerangkan. Selama pengamatan yang peneliti lakukan siswa umumnya masih malu dalam mengemukakan pendapat, takut dan kurang percaya diri. Pada saat diskusi kelompok berlangsung banyak fenomena yang terjadi. Guru nampak kurang menguasai langkah pemebelajaran dan belum mampu menggunakan media dengan baik. Hal ini memicu siswa untuk kurang konsentrasi pada pembelajaran.

Selama diskusi berlangsung ada beberapa siswa masih asyik bercanda dengan temannya, masih juga ada siswa yang melamun karena merasa tidak dilibatkan dalam diskusi. Secara lengkap hasil observasi selama siklus I disajikan sebagai berikut:

\section{Hasil Observasi Psikomotor Belajar}

Data hasil penilaian ranah psikomotor dalam penelitian ini berupa aktivitas siswa kelas IX F SMP Negeri 7 Cilacap selama mengikuti proses pembelajaran IPS dengan penerapan pembelajaran kontekstual berbantuan media. Data diperoleh menggunakan panduan observasi dengan cara memberikan skor pada aspek aktivitas yang dilakukan oleh siswa sesuai dengan kriteria yang telah ditentukan Aspek aktivitas yang diamati ada tujuh yaitu, aspek memperhatikan pelajaran, aspek bertanya, aspek merespon pertanyaan, aktif berdiskusi, aspek mengerjakan tugas, aspek presentasi dan aspek keaktivan mencatat.

Berdasar data hasil observasi diperoleh temuan pada pertemuan pertama total nilai aktivitas siswa kelas IX F sebesar 2.114 atau rata-rata nilai aktivitas sebesar 66 yang masuk dalam kategori tinggi, sedangkan pada pertemuan kedua dicapai total nilai aktivitas sebesar 2.271 atau rata-rata nilai aktivitas sebesar 71 yang masuk dalam kategori tinggi. Apabila dua pertemuan pembelajaran tesebut digabungkan maka diperoleh rerata total nilai aktivitas siswa kelas IX F siklus I sebesar $68,30 \%$ termasuk dalam kategori tinggi yaitu dengan rincian sebagai berikut: aspek memperhatikan pelajaran masuk dalam kategori sangat tinggi dengan jumlah $82,81 \%$, aspek bertanya termasuk dalam kategori sedang dengan jumlah $37,50 \%$, aspek merespon pertanyaan dalam kategori tinggi sebesar $57,81 \%$, aspek aktif berdiskusi termasuk kategori tinggi sebesar $65,63 \%$, aspek mengerjakan tugas termasuk dalam kategori sangat tinggi sebesar 92,19\%, aspek presentasi termasuk kategori sedang dengan nilai sebesar $50,00 \%$ dan aspek aktif mencatat termasuk dalam kategori sangat tinggi dengan nilai sebesar $92,19 \%$.

Rekapitulasi rerata data hasil observasi aktivitas belajar adalah sebagai berikut:

Tabel 5. Rekapituasi Data Hasil Observasi

Aktivitas Belajar Siswa Siklus I

\begin{tabular}{llcccc}
\hline \multirow{2}{*}{ No } & \multirow{2}{*}{ Aspek yang diamati } & \multicolumn{3}{c}{ Nilai pada Pertemuan } & Kategori \\
\cline { 3 - 5 } & & I & II & Rerata & \\
\hline 1 & Memperhatikan Pelajaran & 81,25 & 84,38 & 82,81 & Sangat tinggi \\
2 & Bertanya & 34,38 & 40,63 & 37,50 & Sedang \\
3 & Merespon Pertanyaan & 56,38 & 59,38 & 57,81 & Tinggi \\
4 & Aktif Berdiskusi & 59,38 & 71,88 & 65,63 & Tinggi \\
5 & Mengerjakan Tugas & 90,63 & 93,75 & 92,19 & Sangat tinggi \\
6 & Presentasi & 50,00 & 53,13 & 50,00 & Sedang \\
7 & Aktif Mencatat & 90,63 & 93,75 & 92,19 & Sangat tinggi \\
\hline Rerata Aktivitas Siklus I & & & $\mathbf{6 8 , 3 0}$ & Tinggi \\
\hline
\end{tabular}


Sedangkan untuk mengetahui distribusi data nilai aktivitas belajar siswa kelas IX F SMP Negeri 7 Cilacap tahun pelajaran 2013/2014 yang dilakukan pada dua kali pertemuan proses pembelajaran di kelas disajikan dalam tabel yang tertuang berikut ini:

Tabel 6. Distribusi dan Kategori Nilai Aktivitas Belajar Siswa Siklus I

\begin{tabular}{|c|c|c|c|c|c|c|c|c|}
\hline \multirow{3}{*}{ No } & \multirow{3}{*}{$\begin{array}{c}\text { Nilai } \\
\text { Konversi }\end{array}$} & \multicolumn{4}{|c|}{ Pertemuan } & \multirow{2}{*}{\multicolumn{2}{|c|}{ Total Rerata }} & \multirow{3}{*}{ Kategori } \\
\hline & & \multicolumn{2}{|c|}{ I } & \multicolumn{2}{|c|}{ II } & & & \\
\hline & & Frekuensi & Persentase & Frekuensi & Persentase & Frekuensi & Persentase & \\
\hline 1 & $71-100$ & 19 & 59,37 & 20 & 62,50 & 19 & 59,37 & Sangat tinggi \\
\hline 2 & $51-70$ & 6 & 18,75 & 7 & 21,88 & 7 & 21,87 & Tinggi \\
\hline 3 & $31-50$ & 3 & 9,38 & 3 & 9,37 & 3 & 9,38 & Sedang \\
\hline 4 & $10-30$ & 4 & 12,50 & 2 & 6,25 & 3 & 9,38 & Rendah \\
\hline \multicolumn{2}{|c|}{ Jumlah } & 32 & 100 & 32 & 100 & 32 & 100 & - \\
\hline
\end{tabular}

Dari tabel 6 tersebut dapat dijelaskan bahwa siswa yang melakukan aktivitas sangat tinggi dilakukan oleh 19 siswa atau sebesar 59,37\%, kemudian terdapat 7 siswa atau $21,87 \%$ yang melakukan aktivitas dengan kategori tinggi dan terdapat 3 siswa atau sebesar $9,38 \%$ yang tergolong dalam kategori sedang serta 3 siswa atau sebesar 9,38\% yang tergolong dalam kategori rendah.

\section{Hasil Belajar Siswa Ranah Kognitif}

Data hasil belajar ranah kognitif diperoleh dengan menggunakan tes kompetensi hasil belajar pada pertemuan kedua berupa soal pilihan ganda sebanyak 20 butir. Peneliti melaksanakan post test pada akhir siklus yang dilaksanakan pada hari Kamis tanggal 26 September 2013. Dari data hasil tes kompetensi belajar didapatkan total nilai sebesar 2.430 dengan nilai tertinggi 95,00 kemudian nilai terendah 55,00 dengan nilai rata-rata kelas adalah 75,94. Dari 32 siswa peserta tes kompetensi yang mendapatkan nilai di atas KKM sebanyak 23 siswa atau 71,88\% dan masih terdapat 9 siswa atau $28,13 \%$ siswa yang belum mencapai KKM. Data hasil uji kompetensi disajikan dalam tabel berikut ini:

Tabel 7.Rekapitulasi Nilai Hasil Belajar Siklus I

\begin{tabular}{lll}
\hline No. & Uraian & Hasil Tes Siklus I \\
\hline 1. & Nilai terendah & 55,00 \\
2. & Nilai tertinggi & 95,00 \\
3. & Nilai rata-rata & 75,94 \\
4. & Jumlah siswa nilai di atas KKM & 23 \\
5. & Jumlah siswa nilai di bawah KKM & 9 \\
6 & Prosentase ketuntasan belajar & $71,88 \%$ \\
7 & Prosentase ketidaktuntasan belajar & $28,13 \%$ \\
\hline
\end{tabular}

\section{Refleksi}

Sesuai model PTK dari Kemmis dan Taggart maka setelah melakukan tindakan dan observasi, peneliti bersama kolaborator melakukan refleksi diakhir siklus I. Refleksi ini berupa diskusi dan evaluasi mengenai tindakan pembelajaran yang telah dilakukan. Kemudian dilakukan pembahasan apakah pada siklus I tersebut sudah sesuai dengan yang direncanakan dan menentukan langkah atau tindakan selanjutnya. Apakah tindakan dirasa baik, apakah perlu revisi terhadap jenis tindakan yang diambil atau justru tindakan tersebut dirasa tidak berhasil dan menimbulkan problema dalam proses pembelajaran sehingga perlu diambil tindakan baru.

Hasil refleksi menunjukkan terdapat perubahan yang sangat signifikan pada proses aktivitas pembelajaran dan hasil belajar siswa setelah penerapan pembelajaran kontekstual berbantuan media media massa ini. Kegiatan pembelajaran 
sangat aktif, guru bersifat dinamisator dan fasilitator di kelas, pembelajara tidak dimonopoli oleh guru atau one way traffic, tetapi siswa mulai terlibat aktif dalam pembelajaran, baik dalam memperhatikan penjelasan guru, berdiskusi, bertanya, merespon pertanyaan guru, mengerjakan tugas maupun mencatat materi pelajaran namun apabila dibandingkan dengan tingkat keberhasilan penelitian belum tercapai yaitu Skor pengamatan aktivitas belajar siswa pada pembelajaran kontekstual berbantuan media belum mencapai skor $\geq 71-100$ dengan kategori "Sangat Tinggi" karena baru sampai pada rata-rata $68,30 \%$ dengan kategori "Tinggi". Ketuntasan belajar siswa klasikal juga belum mencapai $\geq 85 \%$ dari jumlah seluruh siswa telah memperoleh nilai $\geq 72$ dengan rata-rata nilai baru mencapai $71,87 \%$. Strategi REACT-nya belum dilaksankan semua dalam proses pembelajaran sehingga harus dilanjutkan ke siklus II.

Strategi pembelajaran kontekstual yang diterapkan dalam penelitian ini adalah REACT yaitu: (1) Relating yaitu guru telah mengaitkan materi pelajaran dengan peristiwa nyata di lingkungan kehidupan siswa. Peristiwa tersebut berupa tindakan yang berbentuk ancaman kemerdekaan dan tindakan yang berupa berbagai usaha untuk mempertahankan kemerdekaan di era global, sehingga pembelajaran mudah dipahami, (2). Experiencing artinya guru telah mengarahkan siswa untuk menemukan langsung peristiwa-peristiwa yang sesuai dengan materi ajar dari media bantu yang digunakan guru yaitu media massa cetak, surat kabar Suara Merdeka. Dengan demikian siswa lebih banyak melakukan eksplorasi pengetahuan sendiri, ((3) Applying yaitu dalam siklus I guru belum menunjukkan kegiatan penerapan pada sistuasi lain dari materi yang diajarkan. Hal ini perlu dijadikan perhatian dan perbaikan pada siklus berikutnya, (4) Cooperating yaitu guru telah menerapkan prinsip ini dengan cara membentuk kelompok diskusi kemudian memberikan kesempatan kepada siswa melakukan learning community, (5) Transferring dalam prinsip ini guru belum tampak penerapannya dalam pembelajaran di siklus I, oleh karenanya dalam siklus berikutnya harus menjadi perhatian.

Penerapan pembelajaran kontekstual berbantuan media massa ini ternyata mampu membangun situasi belajar yang kondusif. Siswa belajar dalam kondisi yang tidak tertekan, tidak tegang, belajar terasa menyenangkan sehingga pada proses pembelajaran siswa tidak bosan. Dari pelaksanaan siklus I ini terdapat keberhasilan dan kendala yang dihadapi yaitu: a) Keberhasilan Tindakan Siklus I adalah (1)Terjadi peningkatan skor rata-rata aktivitas belajar siswa pada tiap pertemuan di siklus I (2) Terjadi kenaikan hasil belajar siswa dari kondisi pra penelitian sampai dengan pelaksanaan siklus I, (3) Terdapat peningkatan kualitas proses pembelajaran dengan penerapan kontekstual berbantuan media massa, siswa lebih memahami materi pembelajaran dan antusias mengikuti pembelajaran. b) KendalaKendala Pelaksanaan Siklus I adalah (1) Guru belum menjalankan rencana tindakan seluruhnya seperti yang telah disusun (REACT) khususnya Applying dan Transferring, (2) Pada saat diskusi kelompok, siswa masih bekerja secara individual walaupun mereka sudah berkelompok tetapi belum bekerja secara optimal, karena siswa belum terbiasa bekerja secara kelompok, (3) Siswa belum percaya diri untuk menyampaikan pendapatnya sendiri, (4) Media cetak yang digunakan guru sebagai alat bantu dalam proses pembelajaran hanya satu jenis, sehingga bersifat monoton, (5) Pembagian waktu dalam proses pembelajaran kurang proporsional, (6) Penataan tempat duduk siswa ketika diskusi dan presentasi siswa kurang diperhatikan. c).Alternatif Solusi Tindakan pada Siklus II yaitu (1) Guru harus menerapkan skenario pembelajaran secara utuh seperti yang direncanakan, (2) Pemberian motivasi atau penguatan kepada siswa agar lebih berani untuk menyampaikan pendapat dalam diskusi, (3) Disiplin dalam distribusi waktu pembelajaran, (4) Media bantu pembelajaran lebih menarik, (5) Penataan tempat diskusi melingkar sehingga peserta diskusi kelompok dapat saling berinteraksi, (6) Menggunakan media bantu baru yang lebih spesifik membantu siswa dalam

\section{Siklus II}

\section{Perencanaan}

Perbaikan yang direncanakan untuk siklus II adalah menyiapkan RPP, menyiapkan media bantu baru untuk pembelajaran yaitu berupa voucher card, voucher card yang disiapkan berjumlah delapan (8), pembuatan slide powerpoint 
dengan materi masih di Standar Kompetensi (SK) 2. Memahami usaha mempertahankan kemerdekaan dengan Kompetensi Dasar (KD) 2.2 Mendeskripsikan peristiwa-peristiwa politik dan ekonomi Indonesia pasca pengakuan kedaulatan.

Fokus utama dalam pembelajaran pada materi politik dan ekonomi pasca kemerdekaan. Juga mempersiapkan lembar observasi dan lembar kerja siswa. Pembuatan handout materi pembelajaran untuk dibagikan ke siswa agar dapat membantu dalam memahami pembelajaran. Guru tetap melakasanakan skenario pembelajaran kontekstual dengan strategi REACT.

Pada tahap perencanaan ini, peneliti dan kolaborator melakukan diskusi mengenai silabus, RPP dan metode pembelajaran yang akan digunakan dalam proses pembelajaran serta penyusunan lembar observasi, maupun penyiapan media pembelajarannya. Media bantu pembelajaran yang disiapkan adalah kertas amplop yang dijadikan sebagai Voucher Card. Peneliti menyiapkan voucher card ini 8 buah, dan akan dibagikan kepada kelompok diskusi dengan 4 anggota setiap kelompoknya. Peneliti dan kolaborator juga membuat slide powerpoint untuk menunjang penjelasan materi pembelajaran.

\section{Pelaksanaan Tindakan}

\section{Pertemuan Pertama}

Penelitian tindakan kelas pada siklus II dilaksanakan sebanyak 2 kali pertemuan/tatap muka. Pertemuan pertama penelitian ini dilaksanakan pada hari Selasa tanggal 1 Oktober 2013 di kelas IXF. Pembelajaran pada jam pertama sampai dengan jam kedua. Guru masuk kelas pukul 07.20 WIB. Pelajaran diawali dengan doa memulai pelajaran yang dipimpin oleh ketua kelas, kemudian setelah selesai berdoa seluruh siswa mengucapkan salam kepada guru. Guru melakukan presensi kehadiran siswa dan tidak ada yang tidak masuk. Materi pembelajaran yang disampaikan pada siklus II pertemuan pertama ini dengan Standar Kompetensi (SK) 2. Memahami usaha mempertahankan kemerdekaan dengan Kompetensi Dasar (KD) 2.2 Mendeskripsikan peristiwa-peristiwa politik dan ekonomi Indonesia pasca pengakuan kedaulatan. KD 2.2 ini akan dibagi dalam dua kali pertemuan.

Guru menyampaikan indicator dan tujuan pembelajaran yang akan dicapai dalam pembelajaran tersebut. Alokasi waktu yang digunakan untuk proses pembelajaran ini adalah 2 x 40 menit (dua jam pelajaran). Fokus pembelajaran pada pertemuan pertama ini adalah peristiwa-peristiwa politik Indonesia pasca pengakuan kedaulatan. Guru menyampaikan presentasi pembelajaran dengan menggunakan Powerpoint melalui LCD. Guru mengajak siswa untuk melihat peristiwa politik Indonesia pasca kemerdekaan, khususnya mendalami kegiatan pemilu di Indonesia. Guru membandingkan antara pemilu di awal kemerdekaan Indonesia dengan pemilu di era reformasi saat ini. Alat slide laser tetap digunakan guru dalam presentasi dengan tujuan dapat mobile dan berada di dekat siswa. Guru membagikan handout materi.

Setelah selesai melakukan presentasi/penjelasan tentang pokok materi, selanjutnya guru membentuk kelompok diskusi. Setiap kelompok beranggotakan empat orang siswa. Pembagian kelompok melanjutkan kelompok yang dibentuk pada waktu pelaksanaan diskusi di siklus I, yaitu urut nomor absen. Hal ini didasarkan pada kondisi pelaksanaan diskusi di siklus I masih kurang aktif disebabkan kurangnya komunikasi dan masih malu-malu dalam menyampaikan pendapat dalam kelompok. Oleh karena itu, dengan pembentukan kelompok yang sama kemudian sistem penempatan kursi tempat duduk untuk melakaukan diskusi dibuat melingkar maka kendala tersebut dapat teratasi dan lebih padu serta aktif.

Selanjutnya guru membagikan voucher card kepada setiap kelompok untuk didiskusikan kepada kelompoknya sesuai dengan materi yang tertera dalam voucher card tersebut. Dari voucher card ini siswa memilah, menganalisis dan mencocokkan antara pernyataan-pernyataan yang ada di voucher card dengan tema yang tertulis di voucher card. Fokus tema dari voucher card pertemuan pertama ini adalah berkaitan dengan peristiwa pemilu I di Indonesia tahun 1955. Pernyataan yang sesuai dimasukkan kembali ke dalam amplop voucher card, sedangkan yang tidak sesuai dikumpulkan dalam amplop putih dan dipisah. Setiap pernyataan yang dipilih benar bernilai 10. Hal tersebut menjadikan siswa antusias dan tertarik mengikuti pembelajaran IPS, karena media ini belum pernah dikenalkan 
dan digunakan pada pembelajaran sebelumnya. Setelah selesai dalam diskusi kelompok kemudian dilanjutkan presentasi tiap kelompok yang dimulai dari kelompok Madura. Dalam setiap sessinya setiap kelompok hanya menanggapi satu kali sanggahan dari kelompok lain. Apabila belum terjadi titik temu antar kelompok akan dibahas dengan guru dan kelas.

\section{Pertemuan kedua}

Peneliti menyusun RPP dan menyiapkan lembar observasi beserta media bantu yang akan digunakan dalam pembelajaran. Media bantu dalam pembelajaran ini tetap menggunakan Voucher Card, serta mempersiapkan alat evaluasi berupa soal-soal post test untuk mengetahui hasil pembelajaran yang telah dilaksanakan dengan pendekatan kontekstual berbantuan media voucher card ini. Uji kompetensi yang akan dilaksanakan adalah berbentuk tes tertulis, pilihan ganda sebanyak 20 butir dan 4 butir soal terkait media bantu dalam pembelajaran yang dilakukan guru untuk mengetahui sikap (afektif) siswa terhadap penggunaan media bantu pembelajaran dalam kompetensi dasar yang ajarkan.

Pembelajaran pada pertemuan kedua ini melanjutkan materi pada pertemuan pertama yaitu Kompetensi Dasar (KD) 2.2 Mendeskripsikan peristiwa-peristiwa politik dan ekonomi Indonesia pasca pengakuan kedaulatan, sedangkan pada pertemuan kedua ini fokus pada peristiwa ekonominya. Guru menampilkan bentuk-bentuk kegiatan ekonomi pasca kemerdekaan melalui tanyangan slide. Guru juga mengkaitkan keadaan ekonomi Indonesia saat ini agar siswa dapat melihat dan mengamati kondisi ekonomi secara nyata yang ada di sekitar tempat tinggalnya. Guru membagikan handout materi.

Setelah penjelasan selesai dilanjutkan dengan diskusi kelompok. Pembagian kelompok diskusi sama dengan pertemuan pertama. Kemudian guru membagikan voucher card kepada setiap kelompok. Tiap-tiap kelompok selanjutnya melakukan diskusi dan analisis terhadap materi yang diterima. Dari voucher card ini siswa memilah, menganalisis dan mencocokkan antara pernyataan-pernyataan yang ada di voucher card dengan tema yang tertulis di voucher card. Fokus tema dari voucher card pertemuan kedua ini adalah berkaitan dengan masalah ekonomi Indonesia pasca kemerdekaan. Pernyataan yang sesuai dimasukkan kembali ke dalam amplop voucher card, sedangkan yang tidak sesuai dikumpulkan dalam amplop putih dan dipisah. Setiap pernyataan yang dipilih benar bernilai 10. Setelah menyelesaikan diskusi di tiap-tiap kelompok kemudian dilanjutkan sessi diskusi kelas. Setiap kelompok melakukan presentasi yang ditanggapi oleh kelompok lain.

Proses diskusi berjalan sangat antusias dan hidup, respon dan tanggapan antar kelompok terlihat responsif, guru menjadi pengamat dan fasilitator diskusi, semua permasalahan yang muncul dari tanggapan kelompok dapat diselesaikan secara tuntas dalam diskusi kelas ini. Siswa sangat tertarik menggunakan media voucher card ini untuk kegiatan pembelajaran. Penguasaan materi dalam sessi diskusi terlihat sangat kuat dari tiaptiap kelompok. Setelah diskusi kelas selesai dilanjutkan dengan refleksi kemudian diakhiri dengan post test.

\section{Observasi}

Pembelajaran sangat menarik, siswa sangat aktif dan antusias selama proses pembelajaran berlangsung. Siswa menyimak pembelajaran dengan tekun. Selama pengamatan, siswa terlihat sudah berani dalam penyampaian pendapat, tidak takut dan sangat percaya diri, komunikasi selama diskusi kelompok terlihat intens. Guru menguasai langkah pembelajaran dan mampu memandu siswa dalam menggunakan media pembelajaran..

\section{Hasil Observasi Psikomotor Belajar}

Berdasar data hasil observasi diperoleh temuan pada pertemuan pertama total nilai aktivitas siswa kelas IX F sebesar 2.600 atau rata-rata nilai aktivitas sebesar 81 yang masuk dalam kategori sangat tinggi, sedangkan pada pertemuan kedua dicapai total nilai aktivitas sebesar 2.857 atau rata-rata nilai aktivitas sebesar 89 yang masuk dalam kategori sangat tinggi. Rerata total nilai aktivitas siswa kelas IX F siklus II sebesar $85,15 \%$ termasuk dalam kategori sangat tinggi yaitu dengan rincian sebagai berikut: aspek memperhatikan pelajaran masuk dalam kategori sangat tinggi dengan jumlah 93,76 \%, aspek bertanya termasuk dalam kategori sedang dengan jumlah $60,94 \%$, aspek merespon pertanyaan dalam kategori sangat tinggi sebesar 85,94\%, 
aspek aktif berdiskusi termasuk kategori sangat tinggi sebesar $89,07 \%$, aspek mengerjakan tugas termasuk dalam kategori sangat tinggi sebesar 98,44\%, aspek presentasi termasuk kategori tinggi dengan nilai sebesar 70,32\% dan aspek aktif mencatat termasuk dalam kategori sangat tinggi dengan nilai sebesar 98,44\%. Rekapitulasi rerata data observasi aktivitas belajar siswa kelas IX F di SMP Negeri 7 Cilacap pada siklus II tersaji dalam tabel berikut ini.

Tabel 8. Rekapituasi Data Hasil Observasi Aktivitas Belajar Siswa Siklus II

\begin{tabular}{llcccl}
\hline \multirow{2}{*}{ No } & Aspek yang diamati & \multicolumn{3}{c}{ Nilai pada Pertemuan } & Kategori \\
\cline { 2 - 5 } & & I & II & Rerata & \\
\hline 1 & Memperhatikan Pelajaran & 90,63 & 96,88 & 93,76 & Sangat Tinggi \\
2 & Bertanya & 59,38 & 60,94 & 60,94 & Tinggi \\
3 & Merespon Pertanyaan & 78,13 & 85,94 & 85,94 & Sangat Tinggi \\
4 & Aktif Berdiskusi & 84,38 & 89,07 & 89,07 & Sangat Tinggi \\
5 & Mengerjakan Tugas & 96,88 & 100 & 98,44 & Sangat tinggi \\
6 & Presentasi & 62,50 & 70,32 & 70,32 & Tinggi \\
7 & Aktif Mencatat & 96,88 & 100 & 98,44 & Sangat tinggi \\
\hline Rerata Aktivitas Siklus II & & & 85,15 & Sangat Tinggi \\
\hline
\end{tabular}

Sedangkan untuk mengetahui frekuensi distribusi data nilai rata-rata aktivitas belajar siswa kelas IX F SMP Negeri 7 Cilacap tahun pelajaran 2013/2014 yang dilakukan pada dua kali pertemuan proses pembelajaran di kelas disajikan dalam tabel yang tertuang berikut ini:

Tabel 9. Distribusi dan Kategori Nilai Aktivitas Belajar Siswa Kelas IX F Siklus II

\begin{tabular}{|c|c|c|c|c|c|c|c|c|}
\hline \multirow{3}{*}{ No } & \multirow{3}{*}{$\begin{array}{c}\text { Nilai } \\
\text { Konversi }\end{array}$} & \multicolumn{4}{|c|}{ Pertemuan } & \multirow{2}{*}{\multicolumn{2}{|c|}{ Total Rerata }} & \multirow{3}{*}{ Kategori } \\
\hline & & \multicolumn{2}{|c|}{ I } & \multicolumn{2}{|c|}{ II } & & & \\
\hline & & Frekuensi & Persentase & Frekuensi & Persentase & Frekuensi & Persentase & \\
\hline 1 & 71-100 & 28 & 87,50 & 31 & 96,87 & 29 & 90,63 & $\begin{array}{c}\text { Sangat } \\
\text { tinggi }\end{array}$ \\
\hline 2 & $51-70$ & 2 & 6,25 & 1 & 3,13 & 2 & 6,25 & Tinggi \\
\hline 3 & $31-50$ & 2 & 6,25 & 0 & 0 & 1 & 3,13 & Sedang \\
\hline 4 & $10-30$ & 0 & 0 & 0 & 0 & 0 & 0 & - \\
\hline \multicolumn{2}{|c|}{ Jumlah } & 32 & 100 & 32 & 100 & 32 & 100 & - \\
\hline
\end{tabular}

Dari tabel 9 tersebut dapat dijelaskan bahwa siswa yang melakukan aktivitas sangat tinggi dilakukan oleh 29 siswa atau sebesar 90,63\%, kemudian terdapat 2 siswa atau $6,25 \%$ yang melakukan aktivitas dengan kategori tinggi dan terdapat 1 siswa atau sebesar 3,13\% yang tergolong dalam kategori sedang.

\section{Hasil Belajar Siswa Ranah Kognitif}

Hasil belajar ranah kognitif diperoleh dengan menggunakan tes kompetensi hasil belajar pada akhir pertemuan kedua. Uji kompetensi ini dilaksanakan dengan soal pilihan ganda sebanyak 20 butir. Peneliti melaksanakan post test pada akhir siklus yang dilaksanakan pada hari Kamis tanggal 3 Oktober 2013. Dari data hasil tes uji kompetensi belajar didapatkan total nilai sebesar 2.515 dengan nilai tertinggi 95,00 kemudian nilai terendah 60,00 dengan nilai rata-rata kelas adalah 78,59. Dari 32 siswa peserta tes kompetensi yang mendapatkan nilai di atas KKM sebanyak 28 siswa atau $87,15 \%$ dan masih terdapat 4 siswa atau $12,5 \%$ siswa yang belum mencapai KKM.

Hasil uji kompetensi kognitif akan digunakan untuk menentukan tingkat keberhasilan pembelajaran siswa kelas IXF apakah siklus II ini memberikan pengaruh yang positif terhadap proses pembelajaran atau tidak. Untuk mengetahui data hasil uji kompetensi kognitf disajikan dalam tabel berikut ini: 
Tabel 10. Rekapitulasi Nilai Hasil Uji Kompetensi Siklus II

\begin{tabular}{llc}
\hline No & Uraian & $\begin{array}{c}\text { Hasil Tes } \\
\text { Siklus II }\end{array}$ \\
\hline 1. & Nilai terendah & 60,00 \\
2. & Nilai tertinggi & 100,00 \\
3. & Nilai rata-rata & 78,59 \\
4. & Jumlah siswa nilai di atas KKM & 28 \\
5. & Jumlah siswa nilai di bawah KKM & 4 \\
6. & Prosentase ketuntasan belajar & $87,50 \%$ \\
7. & Prosentase ketidaktuntasan & $12,50 \%$ \\
& belajar \\
\hline
\end{tabular}

\section{Refleksi}

Hasil refleksi menunjukkan terdapat perubahan yang sangat signifikan pada proses aktivitas pembelajaran dan hasil belajar siswa setelah penerapan pembelajaran kontekstual berbantuan media voucher card. Paduan media powerpoint dan handout juga membuat siswa terlibat aktif dalam pembelajaran. Penggunaan voucher card membuat siswa lebih semangat belajar, terpancar keceriaan siswa selama proses pembelajaran. Kegiatan pembelajaran siswa terlibat aktif, baik dalam memperhatikan penjelasan guru, berdiskusi, bertanya, merespon pertanyaan guru, mengerjakan tugas maupun mencatat materi pelajaran. Keterpaduan kelompok diskusi yang sudah menyatu mampu membuat siswa melibatkan diri secara aktif.

Tingkat keberhasilan penelitian tercapai pada siklus II ini karena skor pengamatan aktivitas belajar siswa pada pembelajaran kontekstual berbantuan media voucher card sudah mencapai skor $\geq 71-100$ dengan kategori "Sangat Tinggi" yaitu $85,15 \%$. Ketuntasan belajar siswa klasikal juga sudah mencapai $\geq 85 \%$ dari jumlah seluruh siswa telah memperoleh nilai $\geq 72$ yaitu $87,50 \%$. Strategi REACT-nya telah dilaksanakan semua dalam proses pembelajaran sehingga penelitian ini dapat diakhiri dan tidak akan dilanjutkan ke siklus III, sedangkan siswa yang belum mencapai batas ketuntasan akan diberi tugas tambahan yang menunjang penguasaan materi pada SK 2 dan KD 2.2 ini.

Komponen dalam pembelajaran kontekstual yang diterapkan dalam penelitian ini adalah REACT yaitu: (1) Relating yaitu guru mengkaitkan materi pembelajaran dengan pemilu Indonesia tahun 2009 dan rencana pemilu tahun
2014 beserta perilaku partai peserta pemilu, selain itu juga mengkaitkan dengan kondisi perekonomian saat ini terutama gejolak ekonomi maupun fluktuasi nilai tukar rupiah terhadap dollar AS, (2) Experiencing artinya guru telah mengarahkan siswa untuk menemukan langsung peristiwaperistiwa pemilu dan keadaan kondisi ekonomi Indonesia saat ini menggunakan media voucher card. Dengan demikian siswa lebih banyak melakukan eksplorasi pengetahuan sendiri, (3) Applying yaitu guru memberikan analog pemilu dengan pemilihan ketua OSIS SMP Negeri 7 Cilacap yang akan dlaksanakan pada tanggal 14 Oktober 2013, ataupun ketika pemilihan pengurus kelas pada awal tahun ajaran baru, sedang untuk kajian bidang ekonomi siswa diperintahkan untuk melakukan observasi berkelompok mengenai kegiatan perdagangan di kantin sekolah pada jam istirahat pertama, untuk kemudian hasilnya dikumpulkan pada tanggal 14 Oktober 2013, (4) Cooperating yaitu guru telah menerapkan prinsip ini dengan cara membentuk kelompok diskusi. Learning community yang dilakukan oleh siswa pada proses pembelajaran diskusi kelas maupun ketika proses observasi kegiatan perdagangan di kantin sekolah, (5) Transferring dalam prinsip ini guru telah memberikan kebebasan kepada setiap kelompok untuk menerapkan dengan mempraktekkan prinsip-prinsip pemilu untuk memilih ketua dan sekretaris kelompok diskusinya, menentukan siapa yang harus presentasi ketika diskusi kelas dari tiap-tiap kelompok

Penerapan strategi REACT dari pembelajaran kontekstual berbantuan media ini ternyata mampu membangun situasi belajar yang kondusif. Siswa belajar dalam kondisi yang tidak tertekan, tidak tegang, belajar terasa menyenangkan sehingga pada proses pembelajaran siswa tidak bosan. Implikasi positif dari pelaksanaan strategi REACT sesuai scenario pembelajaran adalah tercapainya keberhasilan seperti yang ditentukan dalam kriteria keberhasilan penelitian.

Pembahasan

\section{Hasil Belajar Psikomotor}

Penilaian pembelajaran IPS dilakukan secara komprehensif meliputi ranah psikomotor, afektif dan kognitif. Data hasil belajar ranah psikomotor diperoleh dari hasil observasi aktivitas siswa selama proses pembelajaran dari siklus 
I sampai dengan siklus II. Rekapitulasi data aktivitas siswa kelas IXF selama penelitian ini disajikan pada tabel berikut:

Tabel 11. Nilai Aktivitas Siswa dalam Penerapan CTL Berbantuan Media

\begin{tabular}{llccc}
\hline \multirow{2}{*}{ No } & \multicolumn{1}{c}{$\begin{array}{c}\text { Aspek yang } \\
\text { diamati }\end{array}$} & \multicolumn{3}{c}{ Nilai pada Siklus } \\
\cline { 3 - 5 } & \multicolumn{2}{c}{$\begin{array}{c}\text { Pra } \\
\text { Siklus }\end{array}$} & I & II \\
\hline 1 & $\begin{array}{l}\text { Memperhatikan } \\
\text { Pelajaran }\end{array}$ & 59,38 & 82,81 & 93,76 \\
2 & Bertanya & 25,00 & 37,50 & 60,94 \\
3 & Merespon & 43,75 & 57,81 & 85,94 \\
& Pertanyaan & & & \\
4 & Aktif Berdiskusi & 0,00 & 65,63 & 89,07 \\
5 & Mengerjakan Tugas & 78,13 & 92,19 & 98,44 \\
6 & Presentasi & 0,00 & 50,00 & 70,32 \\
7 & Aktif Mencatat & 81,25 & 92,19 & 98,44 \\
\hline Rerata Aktivitas Siklus I & 41,07 & 68,30 & 85,15 \\
\hline Kategori & Sedang & Tinggi & Sangat \\
& & & & tinggi \\
\hline
\end{tabular}

Data peningkatan aktivitas siswa dari pra siklus, siklus I sampai dengan siklus II disajikan pada grafik berikut:

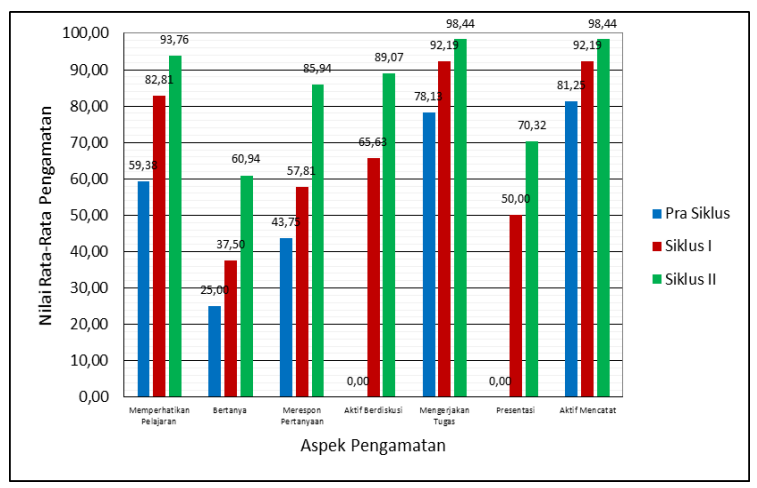

Gambar 2. Grafik Aktivitas Siswa dalam Penerapan Kontekstual Berbantuan Media
Aktivitas siswa selama proses pembelajaran mengalami peningkatan, pada siklus I ratarata aktivitas siswa tergolong sedang yakni 41,07 (lampiran 13), pada siklus I mengalami peningkatan sebesar 27,23\% dari aktivitas pra Siklus menjadi $68,30 \%$ dan pada siklus II juga mengalami peningkatan sebesar $16,84 \%$ menjadi $85,15 \%$.

Peningkatan ini menurut peneliti karena kinerja guru dalam pembelajaran dengan penerapan strategi REACT yang semakin baik. Kemampuan guru dalam mendorong siswa untuk aktif mencari informasi dalam pembelajaran melalui kegiatan diskusi dan pemanfaatan media bantu berdampak pada keaktifan siswa pada aspek amatan yang lain. Peningkatan aktivitas siswa juga dikarena adanya variasi media pembelajaran yang pada siklus I peneliti hanya menggunakan media massa cetak sedangkan pada siklus II peneliti memadukan media voucher card yang dibantu dengan handout dan powerpoint. Siswa terlibat dalam aktivitas yang tinggi mulai dari menyimak pembelajaran, mencari informasi, mengemukakan pendapat, serta mencatat. Penggunaan media yang bervariasi mampu menghindarkan siswa dari kebosanan dan meningkatkan aktivitas siswa.

\section{Penilaian Hasil Belajar Kognitif}

Penilaian terakhir yang umum dilakukan guru adalah penilaian kognitif. Penilaian ini untuk mengetahui seberapa besar kompetensi kognisi yang telah diserap siswa setelah dilakukan proses pembelajaran dengan menggunakan berbagai metode dan media bantu. Untuk mengetahui data peningkatan penilaian hasil belajar kognitif siswa pada penelitian ini dari Kondisi Awal sampai dengan Siklus II dapat terlihat dalam tabel berikut ini:

Tabel 12. Rekapitulasi Perolehan Nilai Kognitif

\begin{tabular}{llccc}
\hline \multirow{2}{*}{ No } & \multirow{2}{*}{ Rincian Nilai Hasil Belajar } & \multicolumn{3}{c}{ Perolehan Nilai } \\
\cline { 3 - 5 } & & Kondisi Awal & Siklus I & Siklus II \\
\hline 1 & Jumlah Total Nilai & 2.250 & 2.445 & 2.550 \\
2 & Nilai Rata-Rata & 70,31 & 76,41 & 79,69 \\
3 & Nilai Tertinggi & 85,00 & 95,00 & 10 \\
4 & Nilai Terendah & 45,00 & 55,00 & 60,00 \\
7 & Siswa Belum Tuntas & 18 & 9 & 4 \\
8 & Persentase Siswa yang Belum Tuntas & 56,25 & 28,13 & 12,5 \\
9 & Siswa Tuntas & 14 & 23 & 28 \\
10 & Persentase Siswa yang Tuntas Belajar & 43,75 & 71,88 & 87,50 \\
\hline Ketercapaian & Belum tercapai & Belum tercapai & Tercapai \\
\hline
\end{tabular}


Dari tabel 12 ditemukan data bahwa jumlah nilai Pra Siklus sebesar 2.255 sedang pada Siklus I 2.445 terjadi peningkatan sebesar 190 kemudian di siklus II jumlah nilai menjadi 2.550 meningkat sebesar 105 , rata-rata nilai juga mengalami peningkatan dari 70,31 pada waktu Pra Siklus menjadi 76,41 atau terjadi peningkatan rata-rata sebesar 6,10 sedangkan pada Siklus II rata-rata nilai siswa menjadi 79,69. Nilai tertinggi yang diperoleh siswa meningkat yaitu dari 85 di Pra Siklus menjadi 95 di Siklus I dan di Siklus II menjadi 100, sedangkan nilai terendah juga meningkat dari 45 pada waktu Pra Siklus menjadi 55 dan 60 pada waktu Siklus II. Besarnya jumlah siswa yang belum tuntas secara kuantitatif mengalami penurunan jumlah dari 18 siswa atau $56,25 \%$ di pra siklus menjadi 9 siswa atau $28,13 \%$ di siklus I dan di akhir siklus II menjadi 4 siswa atau $12,50 \%$, jumlah siswa yang mencapai KKM atau tuntas mengalami peningkatan dari 14 siswa atau $43,75 \%$ di pra siklus menjadi 23 siswa atau $71,88 \%$ si siklus I dan di akhir siklus II menjadi 28 siswa atau $87,50 \%$. Data peningkatan total nilai hasil belajar kognitif siswa dapat dilihat dalam grafik berikut ini:

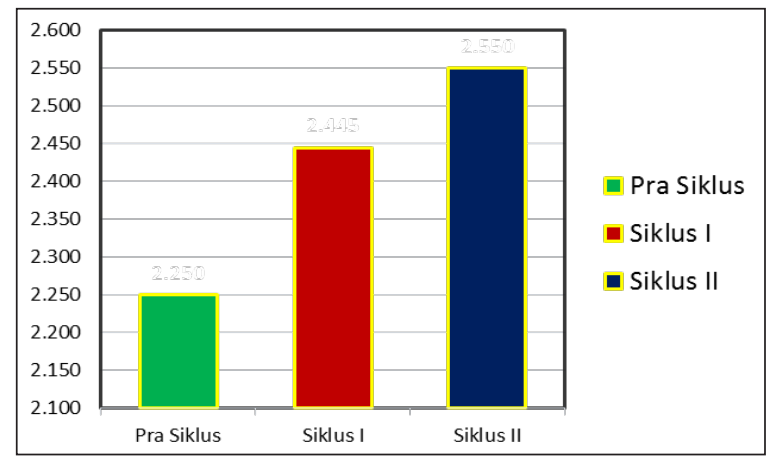

Gambar 3. Grafik Total Nilai Kognitif

Sedangkan rincian peningkatan nilai hasil belajar siswa tersaji dalam grafik berikut ini:

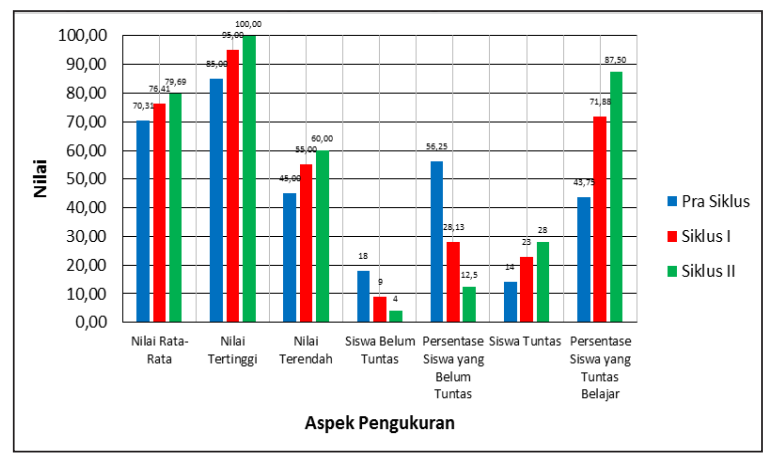

Gambar 4. Rekapitulasi Perolehan Nilai dari Uji Kompetensi Siswa
Distribusi nilai yang diperoleh siswa selama penelitian dapat dilihat dalam tabel berikut:

Tabel 13. Distribusi Frekuensi Nilai Kognitif

\begin{tabular}{|c|c|c|c|c|}
\hline \multirow[b]{2}{*}{ No } & \multirow[b]{2}{*}{$\begin{array}{c}\text { Rentang } \\
\text { Nilai }\end{array}$} & \multicolumn{3}{|c|}{ Frekunsi } \\
\hline & & $\begin{array}{c}\text { Pra } \\
\text { Siklus }\end{array}$ & $\begin{array}{c}\text { Siklus } \\
\text { I }\end{array}$ & $\begin{array}{l}\text { Siklus } \\
\text { II }\end{array}$ \\
\hline 1 & $>71-100$ & 14 & 23 & 28 \\
\hline 2 & $>51-70$ & 16 & 9 & 4 \\
\hline 3 & $>31-50$ & 2 & 0 & 0 \\
\hline 4 & $>10-30$ & 0 & 0 & 0 \\
\hline \multicolumn{2}{|c|}{ Jumlah Siswa } & 32 & 32 & 32 \\
\hline
\end{tabular}

Dari tabel 13 tersebut siswa yang mendapatkan nilai di atas $71-100$ diraih oleh 14 siswa pada pra tindakan kemudian pada siklus I diraih oleh 23 siswa terdapat peningkatan 9 siswa dari keadaan prasiklus, selanjutnya pada siklus II terdapat 28 siswa atau terjadi peningkatan 5 siswa dari kondisi di siklus I, sedangkan siswa yang memperoleh nilai di atas $51-70$, pada pra siklus terdapat 16 siswa kemudian pada siklus I terdapat 9 siswa atau terjadi penurunan 7 siswa sedangkan pada siklus II hanya terdapat 4 siswa atau terjadi penurunan 5 siswa dari sisklus I. siswa yang mendapat nilai di bawah 50 sebanyak 2 pada pra siklus, sedangkan pada siklus I dan siklsu II tidak ditemukan siswa yang memperoleh nilai di bawah 50 .

Distribusi frekuensi perolehan nilai kognitif siswa kelas IXF tersebut dapat disajikan dalam bentuk grafik sebagai berikut:

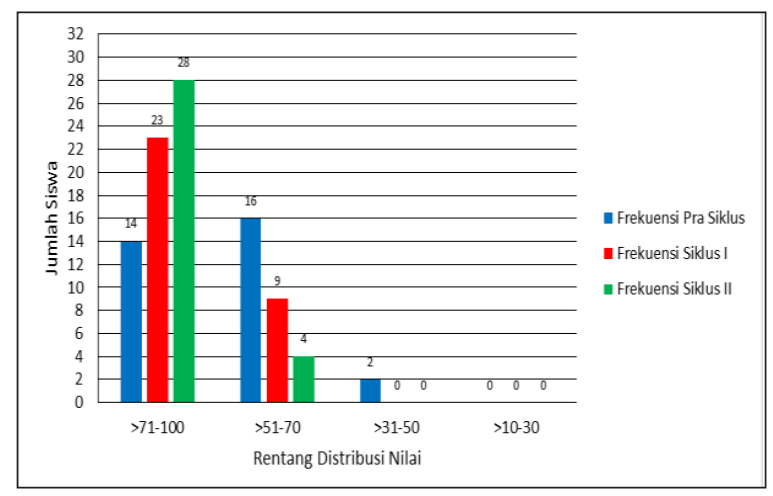

Gambar 5. Distribusi Frekuensi Perolehan Nilai Kognitif

Peningkatana hasil belajar kognitif ini berkaitan erat dengan kinerja guru yang semakin baik dalam pembelajaran. Kemampuan guru yang semakin baik dalam menjalankan scenario pembelajaran atau penerapan pembelajaran 
kontekstual, paduan variasi media yang digunakan mampu meningkatkan pemahaman siswa terhadap materi pembelajaran. Keterampilan guru dalam membimbing siswa berdiskusi secara konstruktivistik dan kontekstual mampu meningkatkan pemahaman siswa. Paduan penggunaan media mampu meningkatkan konsentrasi, aktivitas serta pemahaman siswa terhadap materi pelajaran. Aktivitas siswa yang tinggi dalam menyimak pembelajaran, mencari informasi secara kontekstual, mengajukan pendapat dalam diskusi, maupun presentasi secara langsung dan tidak langsung mampu meningkatkan pemahaman siswa terhadap materi, sehingga hasil belajar siswa semakin meningkat.

Kriteria keberhasilan yang telah ditetapkan untuk mengukur pencapaian nilai hasil belajar kognitif siswa adalah apabila siswa telah mendapatkan nilai $\geq 72$ atau secara klasikal siswa tuntas belajar mencapai $\geq 85 \%$ dari jumlah seluruh siswa siswa. Oleh karenanya melihat data hasil belajar pada siklus II yang telah mencapai ketuntasan klasikal sebesar $87,50 \%$, maka penelitian ini diakhiri dan tidak dilanjutkan ke siklus III.

\section{Simpulan dan Saran}

Simpulan

Pembelajaran Kontekstual dengan Strategi REACT berbantuan media cetak dan voucher card dapat meningkatkan aktivitas belajar siswa pada kelas IX F SMP Negeri 7 Cilacap tahun pelajaran 2013/2014 yaitu sebesar $68,30 \%$ di akhir siklus I dan $85,15 \%$ pada akhir siklus II. Pembelajaran Kontekstual dengan Strategi REACT berbantuan media dapat meningkatkan hasil belajar siswa pada kelas IX F SMP Negeri 7 Cilacap tahun pelajaran 2013/2014. Ketuntasan belajar siswa klasikal mencapai $71,88 \%$ di akhir siklus I dan $87,50 \%$ pada akhir siklus II.

Saran

Sebaiknya guru menerapkan model pembelajaran kontekstual berbantuan media untuk materi pembelajaran yang diberikan kepada siswa karena siswa tahu manfaat dan korelasi materi belajar dan kehidupannya. Guru dalam menerapkan pembelajaran kontekstual harus menguasai langkah pembelajaran dengan baik merumuskan strategi REACT dalam skenario pembelajaran

\section{Daftar Pustaka}

Ajoku, LI. (2013). Professional development of teachers, action planning and utilizing $21^{\text {st }}$ century skills in nigerian schools. Journal of Education and Practice Vol.4, No.15, 15-20.

Anderson, Lorin \& Kratwohl. (2010). Pembelajaran, pengajaran dan assesmen. Yogyakarta: Pustaka Pelajar.

Ayoti, C. et.al. (2013). Factors influencing preparation and utilization of instructional media in teaching kiswahili in selected public secondary schools in kenya. Greener Journal of Educational Research Vol. 3,. P. 108-114.

Battersby, \& Gordon. (2006). Preparing to teach: learning from experiencing. Canada: Routledge

Budininsgsih, A. (2012). Belajar \& pembelajaran. Jakarta: PT. Rineka Cipta.

Cazan, AM. (2013). Teaching self regulated learning strategies for psychology students. Journal Procedia - Social and Behavioral Sciences 78, $743-747$.

CORD. (2012). The react learning strategy, Diakses pada tanggal 12 Desember 2012.

Crawford, A. et.al. (2005). Teaching and learning strategis for the thinking classroom. New York: The International Debate Education Association

Dananjaya, U. (2012). Media pembelajaran aktif. Bandung: Penerbit NUANSA

Ellis, AK. (2010). Teaching and learning elementary social studies (sixth edition): Boston: Seattle Pacific University

Ernst, JV. (2013). Impact of experiential learning on cognitive Outcome in technology and Engineering teacher preparation. Journal of Technology Education Vol. 24 No. 2, 31-40. 
Gafur, A. (2003). Penerapan konsep dan prinsip pembelajaran kontekstual (contextual teaching and learning)/CTL dan desain pesan dalam pengembangan pembelajaran dan bahan ajar. Jurnal Cakrawala Pendidikan UNY Nomor 3 Th. XXII, 273-289.

(2012). Desain pembelajaran: konsep, model dan aplikasinya dalam perencanaan pembelajaran. Yogyakarta: Penerbit Ombak

Gagne, R. (1988). Prinsip-prinsip belajar untuk pengajaran. Surabaya: Usaha Nasional.

Hamalik, O. (2011). Dasar-dasar pengembangan kurikulum. Bandung. PT. Remaja Rosdakarya.

Heinich, et.al (2002). Instructional media and technologies for learning. New Jersey: Columbus Ohio.

Hidayatulloh, MF. (2009). Guru sejati: membangun insan berkarakter kuat \& cerdas. Surakarta: Yuma Pustaka.

Johnson, EB. (2009). Contextual teaching and learning: what it is and why it's here to stay. Newburg Park: Corwin Press, Inc
Kemmis, \& Taggart, (1990). The action research planner (Third edition). Deakin: Deakin University Press.

Majid, A. (2011). Perencanaan pembelajaran: mengembangkan standar kompetensi guru. Bandung: Rosdakarya.

Rusman. (2012). Belajar dan pembelajaran berbasis computer. Bandung: Penerbit Alfabeta.

. (2012). Model-model pembelajaran. Jakarta: PT Raja Grafindo Jaya.

Sanjaya, W. (2008). Perencanaan dan desain sistem pembelajaran. Jakarta: Kencana Prenada Media Group.

. (2012). Strategi pembelajaran berorientasi standar proses pendidikan. Jakarta: Prenada Media Group. (Cetakan ke-7).

Sapriya. (2011). Pendidikan IPS: konsep dan pembelajaran. Bandung. PT Remaja Rosdakarya.

Zuchdi, D. (2010). Humanisasi pendidikan. Jakarta: Bumi Aksara. 